\title{
Phytochemical analysis and in-vitro anti- bacterial and anti-fungal activity of Verbascum arianthum (Benth)
}

Aqsa Tariq ${ }^{1}$, Ghulam Mujtaba Shah ${ }^{1}$, Ahmad Zada ${ }^{1,2^{*}}$, Ahmad $\mathrm{Ali}^{3}$, Amir Zaman Shah $^{4}$ and Iqra Fatima ${ }^{5}$

1. Department of Botany, Hazara University Mansehra KP-Pakistan

2. College of Bioscience and Biotechnology, Yangzhou University Yangzhou, 225009-China

3. Centre for Plant Sciences and Biodiversity, University of Swat, KP-Pakistan

4. College of Horticulture and Plant Protection, Yangzhou University Yangzhou, 225009-China

5. Department of Genetics, Hazara University, KP-Pakistan

*Corresponding author's email: ahmadbotanist@gmail.com,ahmad_botany@hu.edu.pk

Citation

Aqsa Tariq, Ghulam Mujtaba Shah, Ahmad Zada, Ahmad Ali, Amir Zaman Shah and Iqra Fatima. Phytochemical analysis and in-vitro anti-bacterial and anti-fungal activity of Verbascum arianthum (Benth). Pure and Applied Biology. Vol. 10, Issue 3, pp797-806. http://dx.doi.org/10.19045/bspab.2021.100082

\begin{tabular}{llll}
\hline \hline Received: 12/09/2020 & Revised: 20/11/2020 & Accepted: 22/12/2020 & Online First: 09/12/2020 \\
\hline \hline
\end{tabular}

\section{Abstract}

The current research work is to investigate phytochemicals profile of Verbascum arianthum and antimicrobial activity of crude extract. The results showed that Verbascum arianthum contains various important phytochemical like, Flavonoids, Phenols, Quinones, Steroids, Saponins, Tannins, alkaloids, Carbohydrates and Cumarine. To check the antimicrobial activity four bacterial strains as, Escherichia coli, Salmonella typhi, Methicillin resistant staphylococcus aureus, and Pseudomonas aeruginosa were used following agar-well diffusion method. The observed results showed highly significant ant-bacterial activity and among the different extract the leaves methanolic extract are better than stem and root extract against our tested bacterial stains. The extract also tested for antifungal activity and result indicated that the leaves and stem methnolic extract showed highly significant antifungal activity against Aspergilus Niger. Previously the others species of genus Verbescum were screened and found potential antimicrobial activities but Verbascum arianthum was not studied previously so this is the first report on the pharmacognostic studies of Verbascum arianthum and is helpful in the characterization of the crude drug.

Keywords: Antimicrobial Activity; Aspergilus Niger; Phytochemicals; Verbascum Arianthum

\section{Introduction}

Verbascum arianthum Benth. belong to family Scrophulariacea and genus Verbascum. The family Scrophulariaceae contains 190 genera and 4000 species which are mostly found in north hemisphere temperate region [1]. The family includes very important genera Mimulus, Penstemon, Digitalis, Veronica and Verbascum [2]. The genus Verbascum plant contain high amount of saponins and flavonoids and used mostly in folk medicines as anaesthetic healing of wounds agents to treats burns and tumour and also used in eye inflammation and cough [3]. In Turkish medicines some Verbascum species leaves and flowers parts are used to treat various respiratory diseases like cough, bronchitis, asthma and tuberculosis. It is also reported that species of Verbascum is helpful for the treatment of haemorrhoid, pain, fungal infections, diarrhoea, wound healing and also have inhibitory activity against 
influenza viruses B and A2 and murine lymphocytic leukaemia [4].

The floral oil is mostly used for the treatment of skin diseases and also used for soothe earache and external eczema. It was also observed that Verbascum species is used for urinary tract infection, mild sedative and used in tea for abdominal pain. They are traditionally consumed as a tea to relieve abdominal pains, [5-7], the ever increasing resistance of human diseases caused by microorganisms is highly serious medical problem in and has resulted in the need for novel antibiotic prototypes and recent study shows that higher plants are source of antibiotics. Many plants of the genus Verbascum have been used for antimicrobial activities especially Verbascum Thapsus [8]. Plants are major source for new drugs but the potential of higher plant is still unexplored. There are about 250,000-500,000 plants, but only few plants has been studied phytochemically and biological and pharmacological knowledge are too small. The physicochemical parameters provide us information about purity of drug, inorganic composition, and soluble components. Therefore the physicochemical parameters are used in herbal industries to control purity of drug and to reduce the chances of adulteration and also helpful to improve the quality of drugs [9].

Microorganisms caused various diseases and bacteria are listed in the first position among common microorganisms which are responsible for various dangerous diseases associated with HIV/AIDS [10]. In human beings the disease causing bacteria have been considered for morbidity and mortality. The drug designing companies produced a large number of antibacterial drugs but the resistance rate of bacteria to these drugs also increased and now become a global problem [11]. It is observed that in gram negative bacteria the double membrane is the major cause for antibiotic resistance [12]. It was confirmed by literature study that plants are major source for antimicrobial drugs and with reference to antimicrobial agents this work was performed on newly identified plant Verbascum arianthum to study antibacterial and antifungal activity of the specie.

\section{Materials and Methods Collection of plant material}

Fresh leaves bark and root of Verbascum arianthum Benth. Free from diseases were collected from Balakot District Mansehra, Pakistan. The coordinates of the collection area is $34.5482^{\circ} \mathrm{N}, 73.3532^{\circ} \mathrm{E}$.

\section{Phytochemical analysis}

The crude extracts were checked for various chemicals and the solvent used were Ethanol, Methanol and Distilled water. Leaves, root, and stem were formulated in given solvents i.e. (Ethanol, Methanol and Distilled water), in the ratio of 1:10 and 5grams of powder drug was soaked in $50 \mathrm{ml}$ of declared solvents and then placed for 3-4 days by frequently stirring every day. Then filter through Wattman's filter paper, the filtrate was then used for various phytochemical analyses like Sapon, flavonoids, quinine, tannins, carbohydrate, alkaloids, glycoside, terpenoids, phenols, cumarins, pholobutannins, authroquinones and altered oil and fats.

\section{Anti-bacterial activity of Verbascum arianthum Preparation of plant extracts}

The dried plant was ground into fine powder with the help of grinder. 80 percent $(450 \mathrm{ml})$ Methanol was then added into 10gram of powder of each plant part and kept for three days with continuously shaken, at third day after 48 hours the solvent of plant was filter with the help of filter paper. After the process of filtration, methanol was evaporated by using rotary evaporator at $40^{\circ} \mathrm{C}$ while vacuum pressure kept reduces. In this way methanol was separated from plant extract and pure extract was obtained for further study. The semi-solid plant extract i.e. (crude 
methanolic extract) of plants was kept at room temperature. The crude extract of plants was used to check the antibacterial activity by agar well diffusion method.

\section{Media used for growth of bacteria}

\section{a) Nutrient Broth media}

(NB) was prepared by mixing 0.16gram of NB media in $20 \mathrm{ml}$ distilled water for the growth of bacteria and then sterilized for 20 minutes by autoclaving at $121^{\mathrm{O}} \mathrm{C}$. The $\mathrm{p}^{\mathrm{H}}$ was adjusted at 7 .

\section{b) Nutrient agar media}

Nutrient agar media required to performed antibacterial activity and it was prepared by mixing 5.04gram of NA $(28 \mathrm{gm} / \mathrm{l})$ media in $180 \mathrm{ml}$ of distilled water and then sterilized by autoclaving at $121^{\circ} \mathrm{C}$ for 20 minutes. The $\mathrm{p}^{\mathrm{H}}$ was adjusted at 7 .

\section{Sub culturing}

Four strains of bacteria $(P A, S T, E C$ and $M R S A$ ) were used in this study. The bacteria were sub cultured by making slants and nutrient broth media. For making slants, about 7.56 gram NA dissolved in $160 \mathrm{ml}$ of distilled water, then sterilized by autoclaving at $121^{\mathrm{O}} \mathrm{C}$ for 20 minutes. After that sterilized media was allowed to cool for one hour and then media was transferred to each test tubes. Each test tube contains $5 \mathrm{ml}$ media (approximately four test tubes were used for four strains of bacteria); test tubes were covered by cotton plugs and kept at room temperature for making slants. When agar was completely solidified, then bacteria were transferred in each test tube with the help of wire loop. The sterilized loop was touch on bacterial culture and pick up the bacteria and transfers it into test tubes containing Nutrient broth .These test tubes were kept in incubator, flame of spirit lamp was used to sterilize the loop.

\section{Inoculums' preparation}

The inoculums was standardized at with 0.5 McFarland turbidity standard

\section{Swabs preparation}

A prepared and autoclaved cotton swab was used at $37^{\circ} \mathrm{C}$ for 24 hours. Throughout the whole process of sub culturing the wire Media preparation and sterilization

5.04 gram of nutrient agar was dissolved in $180 \mathrm{ml}$ of distilled water in flask $(28 \mathrm{~g} / \mathrm{l})$ .when they were dissolve completely then cover the flask with cotton plug and allow to autoclave at $121^{\circ} \mathrm{C}$ for 20 minutes. After autoclaving, the media was transfer to petri plates. $20 \mathrm{ml}$ in each petri-plate under hygienic conditions and then petri-plates were allowed to cool for one hour at room temperature for solidification of agar.

To check the antibacterial activity of selected plant well diffusion method was used which is described by $[13,14]$ with little changes. Four strains of bacteria were used for antibacterial activity of crude extract of given plant. About 12 petri-plates were autoclaved for 20 minutes and, lawning of bacteria was made on all plates by dipping the cotton swabs in 24 hour old inoculums in test tubes at the angle of $60^{\circ} \mathrm{C}$. After that these plates were labelled. In four plates with the help of cork borer, Four wells was made having diameter of $6 \mathrm{~mm}$. By the use of micropipette, plant extract was poured into wells and other well with negative control (methanol), and Standard antibiotic Vancomycin ( $\mathrm{VA}_{30}$ ) was used as positive control. The agar plates were kept in incubator at $37^{\circ} \mathrm{C}$ for 24 hours. After incubation of 24 hours, inhibition zone made by each plant extract and was measured with help of ruler in millimetre $(\mathrm{mm})$ [15].

\section{Antifungal Activity of Verbascum arianthum}

$7.02 \mathrm{~g}$ of Potato Dextrose agar were dissolved in hundred $\mathrm{ml}$ of distilled water in a flask shake to mix. Then prepared media was autoclave for $20 \mathrm{~min}$ and transferred to petri plat

\section{Procedure}

The plant extract were poured on the whole petri plates before solidifying the media, so 
that the plant extract completely covered the petri plates .After solidifying the media the fungal strain was carefully placed in the centre of the plates, close the petri plates with the lid and left for 7 days at room temperature. After 7 days the results was measured.

\section{Results}

\section{Phytochemical Analysis of Verbascum arianthum}

Different solvent were used like Ethanol, Methanol and Distilled water. The results showed that the ethanol solvent contains alkaloids in stem while methanol and distilled water solvent showed alkaloids in stem and leaves and no alkaloids are present in root extract. The Anthraquinones are present in leaves in both ethanol and methanol solvent while others parts do not contains Anthraquinones in all the solvents. Cumarineare present in all the parts in ethanol solvent while in methanol solvent present in leaves and stem while absent in distilled water solvent. The flavonoids compounds are present in all the parts in each solvent while, Glycoside, oil and Pholobatanins are absent in all the parts in each solvent. The other phytochemicals like, Phenols, Quinones, Steroids, Saponins,
Tannins and Terpenoids are present in all the parts of verbascum arianthum in each solvents as shown in (Table 1).

\section{Anti-bacterial activity of leaves extract}

The methanolic extract of Verbascum arianthum leaves showed significant antibacterial activity against Escherichia Coli and the mean zone of inhibition $24 \mathrm{~mm}$ was observed with Standard Error mean (SE) 0.57 was recorded. The antibacterial activity against Methicillin resistant staphylococcus aureus showed that the mean zone of inhibition $25 \mathrm{~mm}$ was recorded with SE Mean value 2.30. The antibacterial activity of Verbascum arianthum against Pseudomonas aeruginosa bacteria show that the mean zone of inhibition $18.667 \mathrm{~mm}$ with, the SE Mean value 2.33 was recorded. The antibacterial activity against bacteria Salmonella typhi show that the mean zone of inhibition $30 \mathrm{~mm}$ with SE Mean value 1.7321 was observed as shown in (Table $1 \&$ Fig. 1). Similarly the leaf extract show maximum bacterial activity against all selected bacterial strains in comparison to positive control treatment in which Standard antibiotic Vancomycin (VA 30 ) was used as shown in (Table 2 \& Fig. 2).

Table 1. Phytochemical analysis of various parts of Verbascum arianthum

\begin{tabular}{|c|c|c|c|c|c|c|c|c|c|}
\hline Phytochemicals & \multicolumn{3}{|c|}{ Ethanol } & \multicolumn{3}{|c|}{ Methanol } & \multicolumn{3}{|c|}{ Distilled water } \\
\hline \multicolumn{10}{|c|}{ Verbascum arianthum } \\
\hline & Root & Leaves & Stem & Root & Leaves & Stem & Root & Leaves & Stem \\
\hline Alkaloids & $\ldots$ & - & + & _ & + & + & - & + & + \\
\hline Anthraquinon & - & - & - & - & - & - & - & - & - \\
\hline Carbohydrates & - & + & - & - & + & - & - & - & - \\
\hline Cumarine & + & + & + & - & + & + & - & - & - \\
\hline Flavonoids & + & + & + & + & + & + & + & + & + \\
\hline Glycoside & - & - & - & - & - & - & - & - & - \\
\hline Oil & - & - & - & - & - & - & - & - & - \\
\hline Pholobatanins & - & - & - & - & - & - & - & - & - \\
\hline Phenols & + & + & + & + & + & + & + & + & + \\
\hline Quinones & + & + & + & + & + & + & + & + & + \\
\hline Steroids & + & + & + & + & + & + & + & + & + \\
\hline Saponins & + & + & + & + & + & + & + & + & + \\
\hline Tannins & + & + & + & + & + & + & + & + & + \\
\hline Terpenoids & + & + & + & + & + & + & + & + & + \\
\hline
\end{tabular}



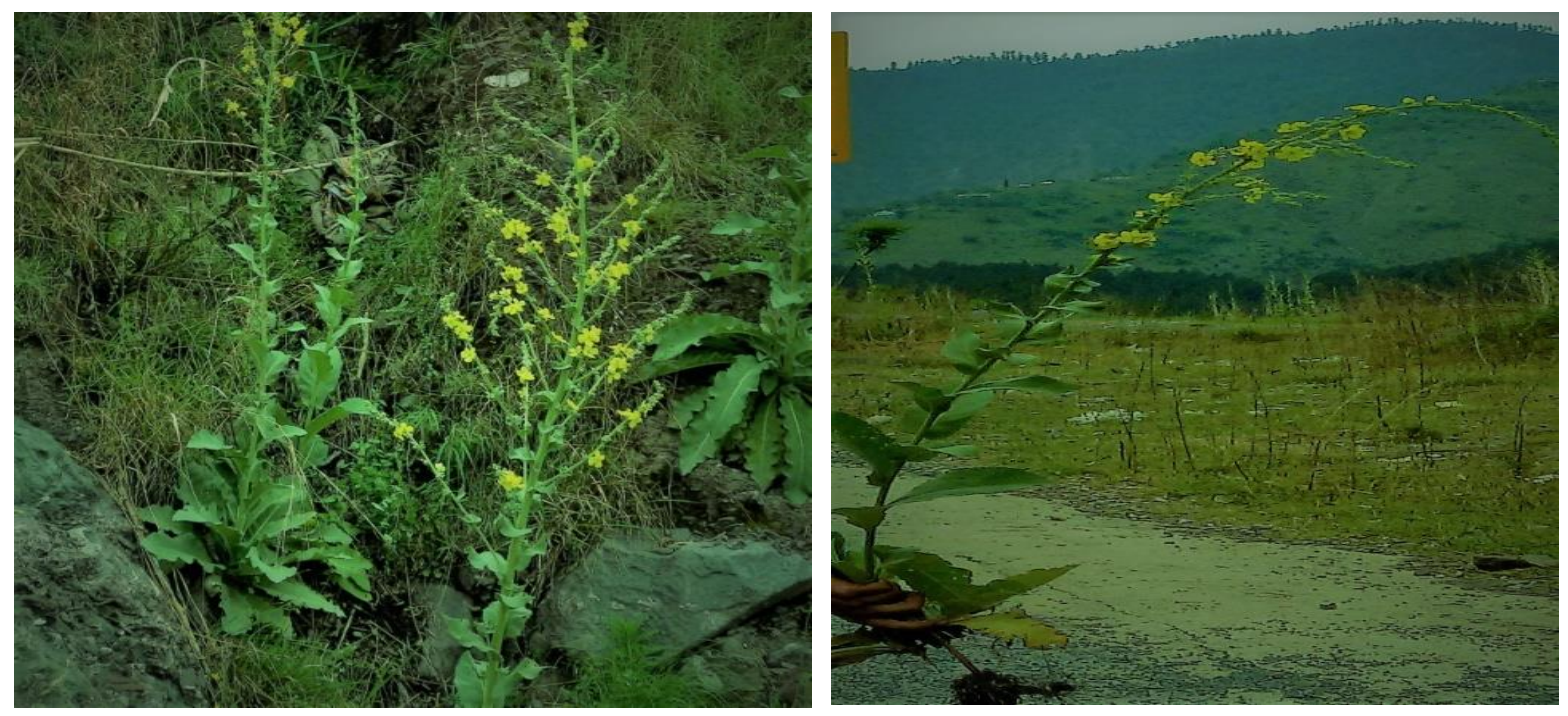

Figure 1. Verbascum arianthum

Table 2. Descriptive statistics of methanolic extract of Verbascum arianthum leaves against selected bacteria

\begin{tabular}{|c|c|c|}
\hline Bacteria & Part used & Mean Zone $( \pm$ SE $)$ \\
\hline Methicillin resistant staphylococcus aureus & Leaves & $24( \pm 0.5774)$ \\
\hline Escheruchia Coli & Leaves & $25( \pm 2.3094)$ \\
\hline Pseudomonas aeruginosa & Leaves & $18.667( \pm 2.3333)$ \\
\hline Salmonella typhi & Leaves & $30( \pm 1.7321)$ \\
\hline
\end{tabular}

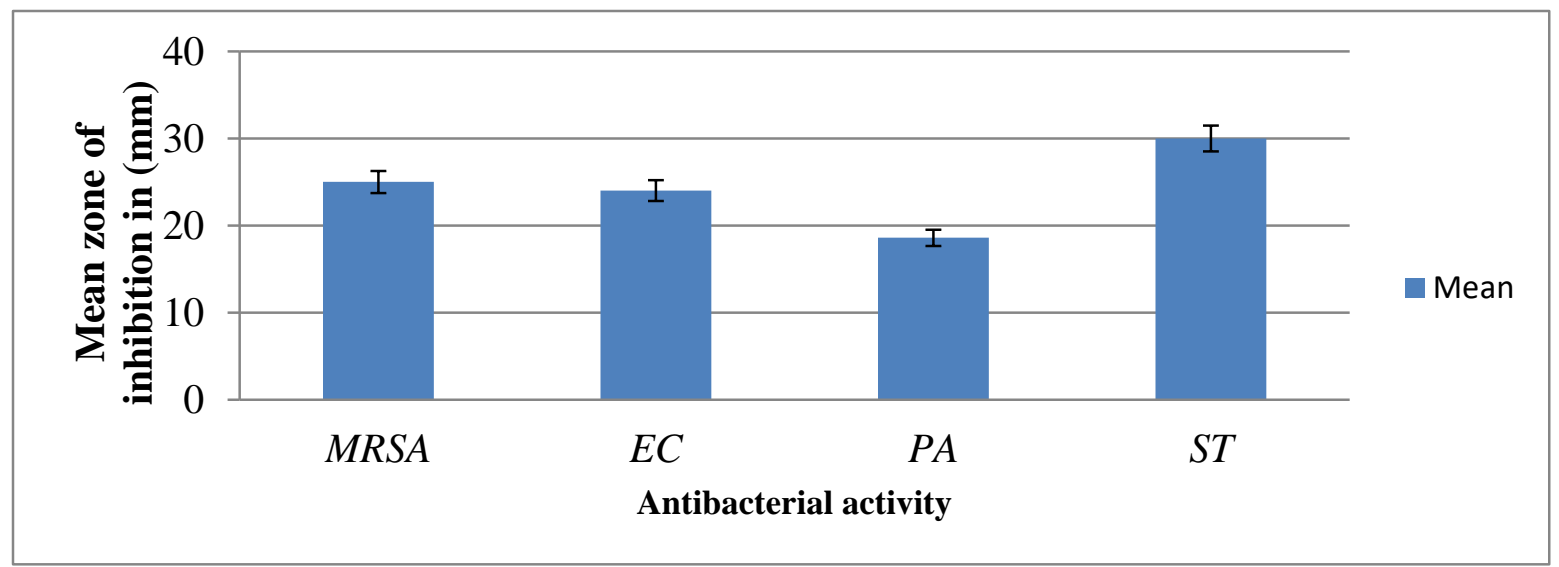

Figure 2. Graphical representation of bacterial activity of Verbascum arianthum leaves

Anti-bacterial activity of stem extract

The methanolic stem extract of Verbascum arianthum show antibacterial activity against Escherichia Coli the mean zone of inhibition $27 \mathrm{~mm}$ was observed with SE mean 1.1547 with CV 7.4074. The antibacterial activity against bacteria Methicillin resistant staphylococcus aureus show that the mean zone of inhibition $12 \mathrm{~mm}$ was recorded and SE Mean value 0.5774 was recorded. The antibacterial activity of Verbascum arianthum against bacteria Pseudomonas aeruginosa show that the mean zone of inhibition $15 \mathrm{~mm}$ and SE Mean value 1.7321 
was recorded. The antibacterial activity against Salmonella typhi bacteria show that the mean zone of inhibition $25 \mathrm{~mm}$ and SE Mean value 1.1547 was observed as shown in (Table 2 \& Fig. 2).Similarly stem extract also exhibit significantly high anti-bacterial activity against all selected bacterial strains in comparison to positive control treatment in which Standard antibiotic Vancomycin (VA 30 ) was used as shown in (Table 3 \& Fig. 3).

Table 3. Descriptive statistics of methanolic extract of Verbascum arianthum stem against selected bacteria

\begin{tabular}{|c|c|c|}
\hline Bacteria & Part used & Mean Zone $( \pm$ SE) \\
\hline Methicillin resistant staphylococcus aureus & stem & $12( \pm 0.5774)$ \\
\hline Escheruchia Coli & stem & $27( \pm 1.15)$ \\
\hline Pseudomonas aeruginosa & stem & $15( \pm 1.7321)$ \\
\hline Salmonella typhi & stem & $25( \pm 1.1547)$ \\
\hline
\end{tabular}

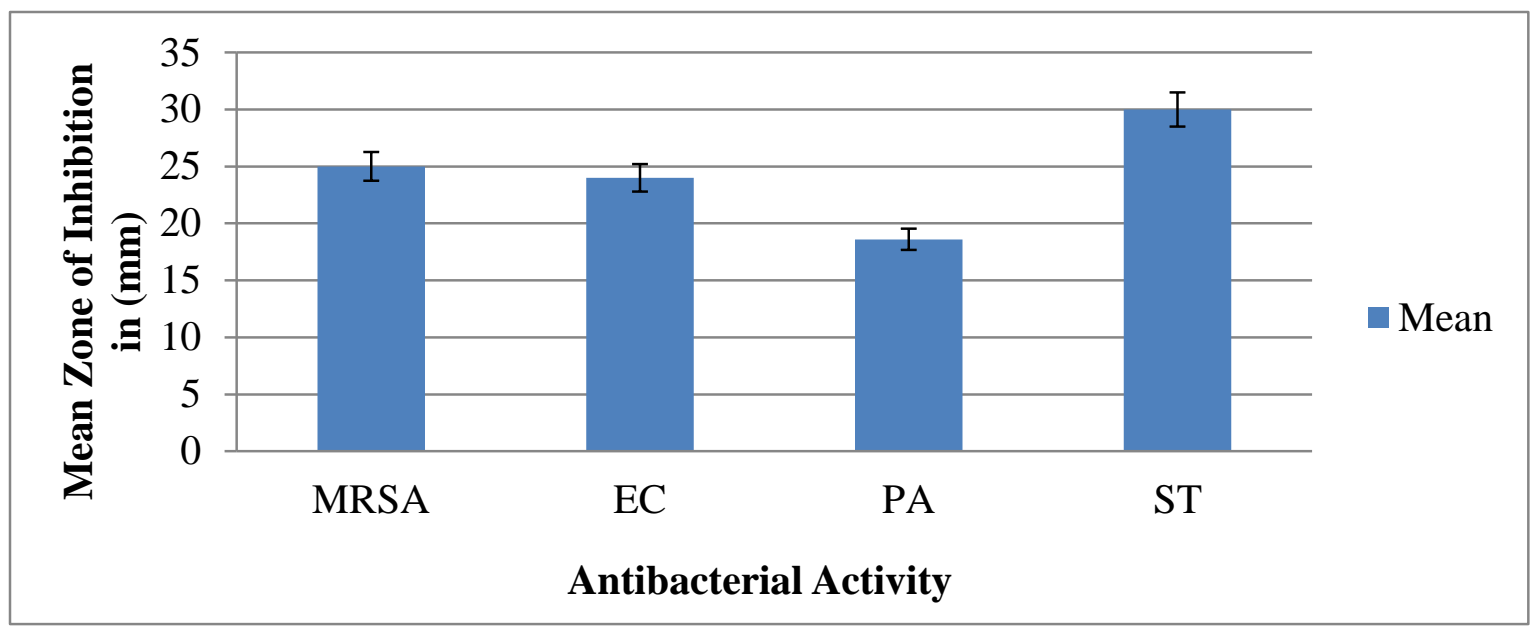

Figure 3. Graphical representation of bacterial activity of Verbascum arianthum stem

\section{Anti-bacterial activity of root extract}

The methanolic root extract of Verbascum arianthum show antibacterial activity against all selected bacterial strains. Against Escherichia Coli the mean zone of inhibition $24 \mathrm{~mm}$ was observed and SE means 0.57 was recorded. The antibacterial activity against bacteria Methicillin resistant staphylococcus aureus show that the mean zone of inhibition $25 \mathrm{~mm}$ was recorded and SE Mean value 2.30 was observed. The antibacterial activity of Verbascum arianthum against Pseudomonas aeruginosa bacteria show that the mean zone of inhibition $18.667 \mathrm{~mm}$ and SE Mean value 2.33 was recorded. The antibacterial activity against Salmonella typhi bacteria show that the mean zone of inhibition $30 \mathrm{~mm}$ and SE Mean value 1 was observed as shown in (Table 3 \& Fig. 3). Similarly root extract also exhibit significantly high anti-bacterial activity against all selected bacterial strains in comparison to positive control treatment in which Standard antibiotic Vancomycin (VA 30 ) was used as shown in (Table 4 \& Fig 4).

\section{Positive control anti-bacterial activity}

Standard antibiotic was used for control. Vancomycin $\left(\mathrm{VA}_{30}\right)$ was used against ria .Methicillin resistant Staphylococcus aureus Escherichia coli, Salmonella typhi and pseudomonas aeruginosa (Table 5 \& Fig. 5). 
Table 4. Descriptive statistics of methanolic extract of Verbascum arianthum roots against selected bacteria

\begin{tabular}{|c|c|c|}
\hline Bacteria & Part used & Mean Zone $( \pm$ SE) \\
\hline Methicillin resistant staphylococcus aureus & Roots & $25( \pm 2.3)$ \\
\hline Escherichia Coli & Roots & $24( \pm 0.57)$ \\
\hline Pseudomonas aeruginosa & Roots & $18.6( \pm 2)$ \\
\hline Salmonella typhi & Roots & $30( \pm 1)$ \\
\hline
\end{tabular}

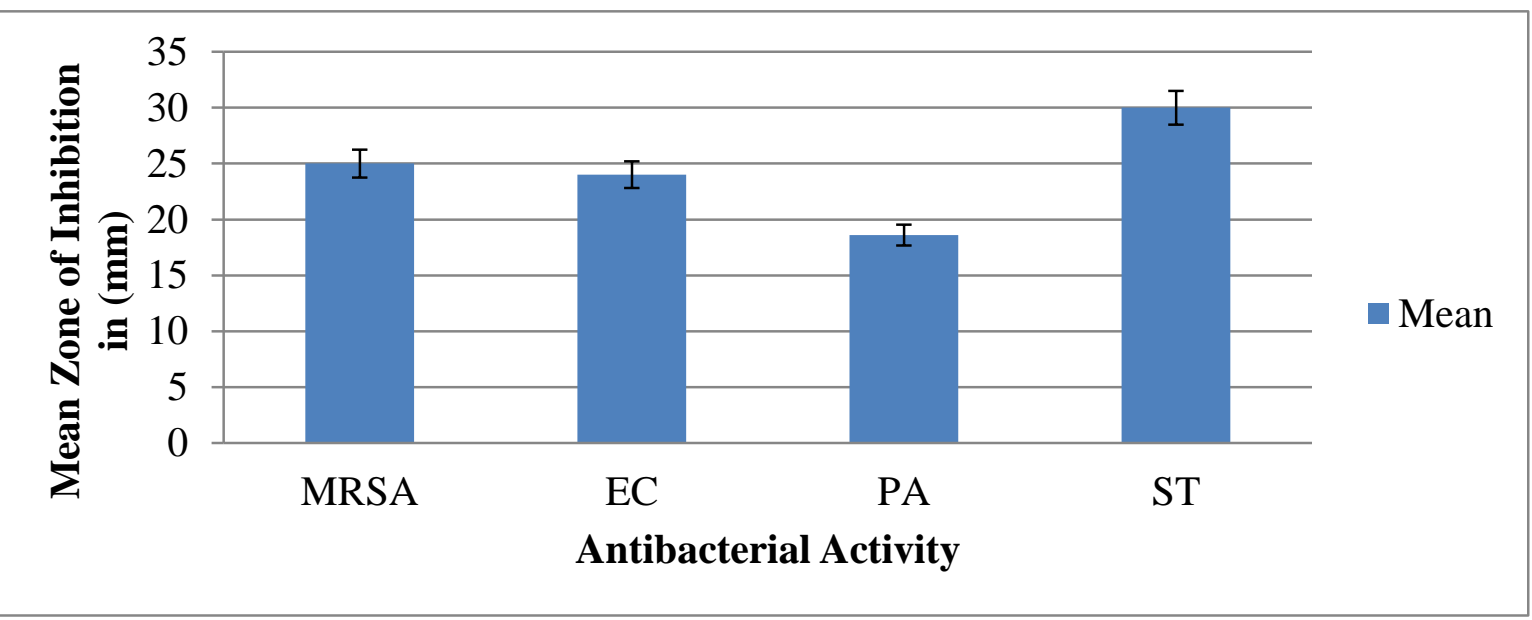

Figure 4. Graphical representation of bacterial activity of Verbascum arianthum Root

Table 5. Positive control anti-bacterial activity

\begin{tabular}{|c|c|c|c|c|}
\hline Positive Control & Antibiotic & Concentration(ug/ml) & $\begin{array}{c}\text { Incubation } \\
\text { period }\end{array}$ & $\begin{array}{c}\text { Zone of } \\
\text { inhibition(mm) }\end{array}$ \\
\hline $\begin{array}{c}\text { Methicillin resistant } \\
\text { staphylococcus aureus }\end{array}$ & Vancomycin & 30 & $24 \mathrm{hrs}$ & $11 \mathrm{~mm}$ \\
\hline Escherichia Coli & Vancomycin & 30 & $24 \mathrm{hrs}$ & $13 \mathrm{~mm}$ \\
\hline Pseudomonas aeruginosa & Vancomycin & 30 & $24 \mathrm{hrs}$ & $17 \mathrm{~mm}$ \\
\hline Salmonella typhi & Vancomycin & 30 & $24 \mathrm{hrs}$ & $9 \mathrm{~mm}$ \\
\hline
\end{tabular}

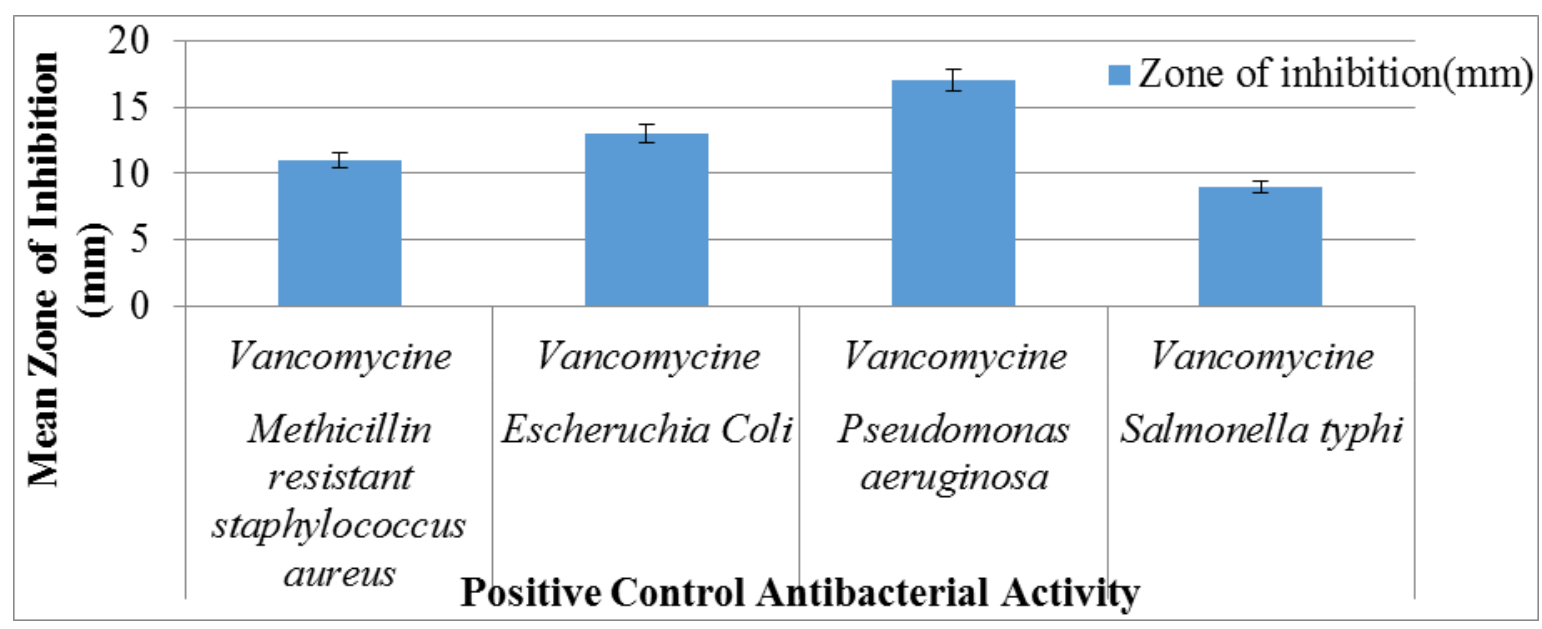

Figure 5. Graphical representation of bacterial activity of positive control 


\section{Antifungal activity}

The methanolic extract of leaves of Verbascum arianthum showed antifungal activity against Aspergillus Niger $10 \mathrm{~mm}$ inhibition zone was observed with SD 1 and variance 1 , similarly SE mean 0.57 with $\mathrm{CV}$ 10 was recorded while less inhibition zone $9 \mathrm{~mm}$ and high inhibition zone $11 \mathrm{~mm}$ was recorded. Similarly the methanolic extract of root of Verbascum arianthum also show antifungal activity against Aspergillus niger and $29 \mathrm{~mm}$ inhibition zone was observed with SD 1 and variance 1, similarly SE mean 0.577 with CV 3.44 was recorded while less inhibition zone $28 \mathrm{~mm}$ and high inhibition zone $30 \mathrm{~mm}$ was recorded. The methanolic extract of stem of Verbascum arianthum also exhibit antifungal activity against Aspergillus niger the and $12 \mathrm{~mm}$ inhibition zone was observed with SD 1 and variance 1, similarly SE mean 0.5774 with CV 8.33was recorded while less inhibition zone $11 \mathrm{~mm}$ and high inhibition zone $13 \mathrm{~mm}$ was recorded which is shown in (Table 6 \& Fig. 6).

Table 6. Descriptive Statistics of Root, stem and leaves extract against Aspergillus Niger

\begin{tabular}{|c|c|c|}
\hline Part Used & Fungal Strain & Mean Zone $( \pm$ SE $)$ \\
\hline Leaves & Aspergillus niger & $12( \pm$ SE 0.57$)$ \\
\hline Root & Aspergillus niger & $29( \pm$ SE 0.577) \\
\hline Stem & Aspergillus niger & $10( \pm$ SE 0.5774 $)$ \\
\hline
\end{tabular}

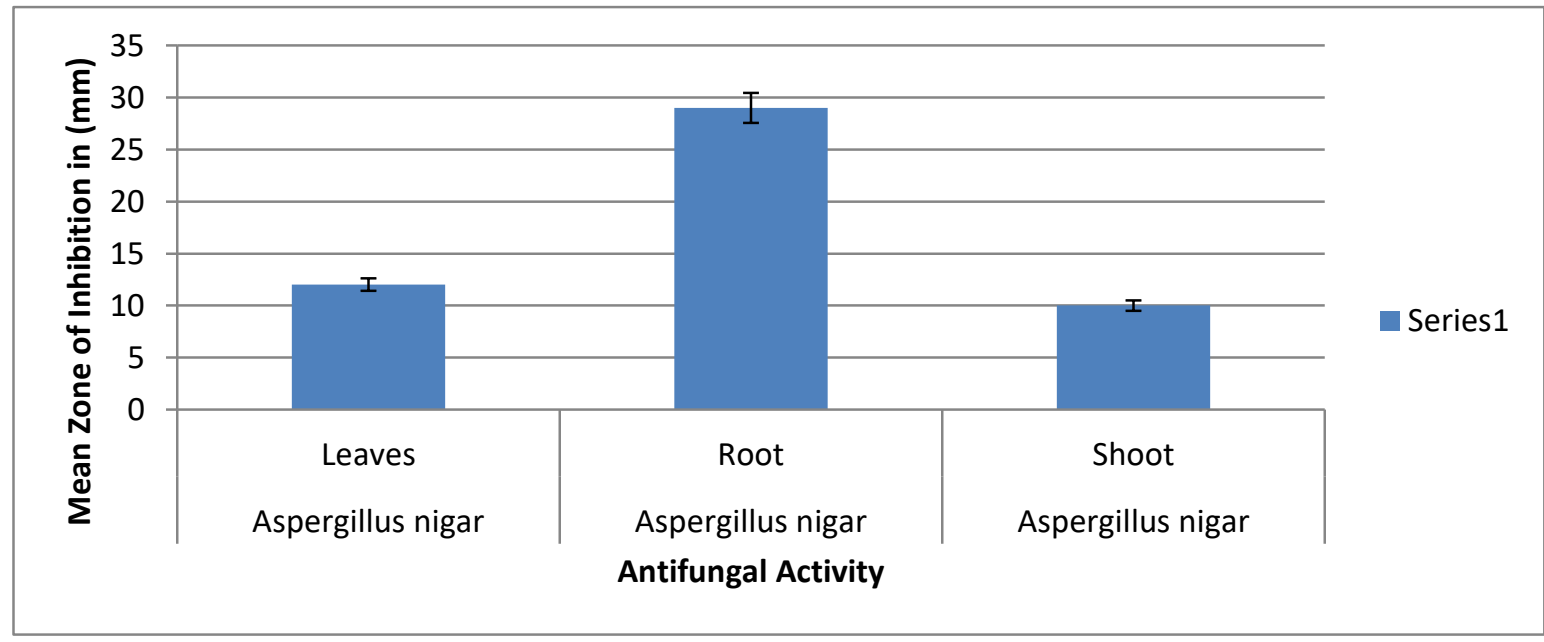

Figure 6. Graphical representation of anti-fungal of Verbascum arianthum

\section{Discussion}

Medicinal plants are the major source for the development of the new chemotherapeutic agents. The initial step towards this goal is the antibacterial assay and pharmacognostic evaluation [16].the importance of plants derived agents for the control of various diseases has been increased in last decades [17]. Due to the presence of bioactive compounds most of the plant showed biological activities [18]. The literature study shows that various reports are available on the antimicrobial properties of the plants [19]. The phytochemical analysis of Verbascum arianthum showed that the presence of carbohydrates, alkaloids, Cumarine, flavonoids, phenols, quinones, steroids, saponins, tannins and terpenoids. The phytochemical contents have the great potential to improve health status. The current study revealed the presence of various bioactive compounds which are used as a lead compound for synthesizing drugs to treat various diseases. 
The literature study showed that alkaloids are most efficient therapeutically significant phytochemical [20]. [21] Reported that pure alkaloids and their derivatives are the in to their major medicinal agents due to their antimicrobial properties. It is also reported that alkaloids can be used for the treatment cold, fever and chronic catarrh [22]. Tannins molecules are used for antimicrobial and anti-oxidant activity [23] and flavonoids molecules are also well known for antioxidant activity and hence they help to protect the body against cancer and other degenerative disease such as Arthritis and Type II diabetes mellitus [24] Glycosides are used for heart problems. The presence of these phytochemicals compounds in Verbascum arianthum is responsible for the observed biological activity.

The root, stem and leaf, extract showed low to high antibacterial and antifungal activity against used bacterial and fungal strains and our result in general agreement with [25] they observed that Verbascum thapsus was tested for its antimicrobial properties against selected human pathogens. Results obtained revealed that the tested plant extracts possess considerable potential antibacterial activity against Escherichia coli, Yersinia pestis, Pseudomonas aeruginosa, Bacillus cereus, Listeria monocytogenes and Staphylococcus aureus.

\section{Conclusion}

It is concluded that Verbascum arianthum (Benth) extract from different parts showed significant antimicrobial activity. Methanolic leaf extract was more effective and showed best results against all tested bacterial strains. The extract from leaves showed more inhibition effect in gram- positive strains bacteria than in gram- negative bacteria it is also observed that the leaf of Verbascum arianthum showed significant anti-fungal activity against studied fungal strain. The possible reasons for this anti-fungal and antibacterial activity of Verbascum arianthum
(Benth) are presence various secondary metabolites in plant like alkaloids, Carbohydrates, Cumarine, Flavonoids, Phenols, Quinones, Steroids, Saponins, Tannins, and Terpenoids.

\section{Authors' contributions}

Conceived and designed the experiments: GM Shah, Performed the experiments: A Tariq, Analyzed the data: A Ali, Contributed reagents/ analysis tools: I Fatima \& AZ Shah, Wrote the paper: A Zada.

\section{Acknowledgments}

The research work did not receive any specific grant from funding agencies in the public, commercial, or not-for- profit sectors.

\section{References}

1. Cronquist A, Takhtadzhiāñ AL (1981). An integrated system of classification of flowering plants: Columbia university press.

2. Frezza C, Bianco A, Serafini M, Foddai S, Salustri M, Reverberi M, et al. (2019). HPLC and NMR analysis of the phenylethanoid glycosides pattern of Verbascum thapsus L. cultivated in the Etnean area. Nat Produ Res 33(9):1310-1316.

3. Shakeri A, Farokh A (2015). Phytochemical evaluation and antioxidant activity of Verbascum sublobatum Murb. leaves. Res J Pharmaco 2(3): 43-47.

4. Tali İI, Akdemir ZS, Bedir E, Khan IA (2004). Saponin, Iridoid, Phenylethanoid and Monoterpene Glycosides from Verbascum pterocalycinum \} var. mutense. Turkish J Chem 28(1):111-122.

5. Aydin C, Rakhimzhanova A, Kilinçarslan O, Mammadov R (2020) Antioxidant and Phenolic Characterization with HPLC of Various Extract of Verbascum glomeratum Linneus. J Chem Soci Pak 42(2): 222-227.

6. Turker AU, Gurel E (2005). Common mullein (Verbascum thapsus L.): recent advances in research. Phytother Res: An Inter J Devo Pharmaco and Toxico Eval Nat Prod Deri 19(9): 733-739.

7. Tatli II, Akkol EK, Yesilada E, Akdemir ZS (2008) Antinociceptive and anti- 
inflammatory activities of seven endemic Verbascum species growing in Turkey. Pharmace Biol 46(10-11): 781-788.

8. Meurer-Grimes B, McBeth DL, Hallihan B, Delph S (1996) Antimicrobial activity in medicinal plants of the Scrophulariaceae and Acanthaceae. Inter J Pharmaco 34(4): 243-248.

9. Mahek A, Tanveer N, Jayalakshmi S (2011) Pharmacognostical standardisation and physico-chemical valuations of leaves of Verbascum thapsus Linn. Int J Drug Dev Res 3: 334-340.

10. Rathee D, Rathee P, Rathee S, Rathee D (2016). Phytochemical screening and antimicrobial activity of Picrorrhiza kurroa, an Indian traditional plant used to treat chronic diarrhea. Arab J Chem 9: S1307-S1313.

11. Adwan G, Mhanna M (2009). Synergistic effects of plant extracts and antibiotics on Staphylococcus aureus strains isolated from clinical specimens. Asian Pacific $J$ Trop Med 2(3): 46-51.

12. Lomovskaya O, Bostian KA (2006). Practical applications and feasibility of efflux pump inhibitors in the clinic - a vision for applied use. Biochem Pharmaco 71(7): 910-918.

13. Carron E, Maran J, Montero L, Fernandozalgo A, Dominguez A (1987). Antimicrobial properties of some extracts obtained from some Mediterranean plants of medicinal value. Plantes Med. et Phyto 21: 195-202.

14. Stepanović S, Antić N, Dakić I, ŠvabićVlahović M (2003). In vitro antimicrobial activity of propolis and synergism between propolis and antimicrobial drugs. Microbiol Res 158(4): 353-357.

15. Kannan L, Liyanage R, Lay Jr JO, Rath NC (2009). Evaluation of beta defensin 2 production by chicken heterophils using direct MALDI mass spectrometry. Mol Imm 46(15): 3151-3156.
16. Tona L, Kambu K, Ngimbi N, Cimanga K, Vlietinck A (1998). Antiamoebic and phytochemical screening of some Congolese medicinal plants. $J$ Ethnopharmaco 61(1): 57-65.

17. Mensah J, Okoli R, Turay A, Ogie-Odia E (2009). Phytochemical analysis of medicinal plants used for the management of hypertension by Esan people of Edo state, Nigeria. Ethnobot Leaflets. (10): 7.

18. Prabuseenivasan S, Jayakumar M, Ignacimuthu S (2006). In vitro antibacterial activity of some plant essential oils. BMC Compl Alter Med 6(1): 39.

19. Samy RP, Ignacimuthu S (2000). Antibacterial activity of some folklore medicinal plants used by tribals in Western Ghats of India. J Ethnopharm 69(1):63-71.

20. Njoku P, Akumefula M. (2007). Phytochemical and nutrient evaluation of Spondias mombin leaves. Pak J Nutr 6(6): 613-615.

21. Stray F. Tiger Books International (1998).The Natural Guide to Medicinal Herbs and Plants. 12-6.

22. Daniel M, Robin EM (2011). Phytochemical and pharmacognostic studies on the bark and leaves of Barringtonia acutangula gaertn

23. Okwu DE, Josiah C (2006). Evaluation of the chemical composition of two Nigerian medicinal plants. African J Biotech 5(4): 357-361.

24. Lee K-G, Shibamoto T (2002). Determination of antioxidant potential of volatile extracts isolated from various herbs and spices. J Agri Food chem 50(17):4947-5492.

25. Prakash V, Rana S, Sagar A (2016). Studies on antibacterial activity of Verbascum thapsus. J Med Plants Stud 4(3): 101-113. 